\title{
Models of Management Formation: Implications for Central and Eastern Europe
}

\author{
Vincent Edwards, Gloria Lee
}

Management formation and management development have been one of the boom industries in Central and Eastern Europe (CEE) in the 1990s. Although managers in the former command economies were well educated and technically competent, their training and experience left them ill equipped to deal with the demands of the newly emerging market economies. This paper reviews different models of management formation in Western Europe and contrasts these with the situation in CEE to evaluate their relevance for the needs of Central and East European managers. A differentiated approach is proposed which takes into account the cultural and economic context of individual countries in the region.

Die Managementbildung und -ausbildung sind in den 90er Jahren eine der boomenden Dienstleistungen in Mittel- und Osteuropa. Obwohl Manager in den ehemaligen Planwirtschaften gut ausgebildet und technisch fähig waren, waren sie infolge ihrer Ausbildung und Erfahrung schlecht gerüstet, um den Anforderungen der neu gegründeten Marktwirtschaften gerecht zu werden. Dieser Artikel legt verschiedene Modelle der Managementbildung in Westeuropa dar und vergleicht diese mit der Situation Mittel- und Osteuropas, um derer Relevanz für die Anforderungen auszuwerten, die an mittel- und osteuropäische Manager gestellt werden. Eine differenzierte Behandlung der Managementbildung wird vorgeschlagen, die den kulturellen und wirtschaftlichen Kontext der einzelnen Staaten der Region berücksichtigt.

\footnotetext{
* manuscript received: 27.5.1998, revised: 19.1.1999, accepted: 10.5.1999

** Edwards, Vincent, 1947, BA (Hons), MA, MBA, PGCE, Professor of East European Management and Culture, Buckinghamshire Business School, Buckinghamshire Chilterns University College, management in Central and Eastern Europe and other transitional economies. Lee, Gloria, (b.: 1931), Professor of Change Management, Buckinghamshire Business School, Buckinghamshire Chilterns University College, Chalfont St Giles, Buckinghamshire, UK, Main Research Topics: Comparative studies of the management of change: management formation and development, export behaviour of smaller firms, development of the multi-media industry; global studies of technological change amongst manufacturing organisations; the formation and careers of production and operations managers.
} 


\section{Introduction}

The transformation process in Central and Eastern Europe has brought about a massive change in the availability and scope of management development. Management education at the undergraduate and postgraduate levels is being offered by a range of providers - public and private, national and foreign frequently working in collaboration. In general American practice is being (super)imposed on a variety of national traditions and practices. To a lesser extent, practice is being influenced by West European models of management development, in the form of cooperative ventures between local and West European companies and academic institutions. Universities in the region are thus offering courses leading to academic awards of Western universities which understandably are highly prized.

It is, however, difficult at this stage to identify whether foreign practices are simply being adopted or whether a distinctive regional model of management formation is emerging. The current situation reveals an interplay of various influences and models. One could argue that the current situation presents a rich tapestry of competing ideas and practices derived from the past and the present and it is difficult to devine how these various forces will interact and coalesce.

This paper traces the implications of certain common pedagogical traditions and economic experiences that have led to contrasting models of management formation in different parts of Europe (Edwards and Lee 1997). Comparisons are made within and between Western Europe and Central and Eastern Europe (CEE). The paper argues that, as well as importing good practice, individual countries within CEE also need to build on existing traditions in order to create a managerial cadre in tune with its social and cultural environment.

The work has arisen through the involvement over many years of the authors in management education and development in Europe and North America. It is based upon research, scholarship, observation, interviews with key informants and membership of and activities within various professional bodies in those regions. With regard to CEE the authors have first-hand knowledge of management and/or management development in East Germany, Hungary, Slovenia and Russia (Edwards and Lawrence, 1994; Bögel et al., 1997; Edwards and Lawrence, 1995; Edwards et al., In press; Lee and Smith, 1992).

\section{Roots of Management Education and Development}

As the pathways to careers in management appear to differ considerably across Europe, it is tempting to assume that each country has developed a unique system, according to its historical, cultural and socio-economic conditions. Because of these varied conditions a distinctive managerial cadre has developed in each European country. We believe nevertheless that it is possible to discern 
three dominant patterns of management formation in Western Europe which we have identified as Anglo-Saxon, Romance and Nordic.

The Anglo-Saxon tradition originated in Britain and together with Ireland remains distinctive in Europe. It can also be seen as the basis of management education in North America but which in turn has exported back to Britain many traditions, especially in the field of management postgraduate taught courses, of which a prime example is the MBA. The Anglo-Saxon tradition is one which distinguishes clearly between management, which is a generalist activity based upon entrepreneurial flair and driven by a profit motive and the professions, with their ethos of service to the community, with the latter having historically enjoyed much higher social status in Britain.

The Romance tradition finds its origins in French intellectual elitism, but has also influenced management formation in Belgium and to a lesser extent in Italy and Spain. France has a unique higher education system, in the form of grandes écoles, which originated to develop engineers and administrators to implement state policy (Gordon 1994). These grandes écoles have remained elitist and distinctive from the university sector in France. The Nordic Model has been founded upon the German engineering tradition and the concept of Technik, as the core of management. Lawrence defines Technik as the application of specialist knowledge and experience, which has no equivalent in English but which is found in other Nordic languages, as in Technik in Dutch and Teknik in Swedish (Lawrence 1994:547).

\section{Management Formation in Central and Eastern Europe}

Before expanding on these West European models, we will present an overview of management formation in the former command economies of Central and Eastern Europe. Clearly such an overview, encompassing the past and current situations in the countries of the region, will be conducted at a high degree of generalization. It is all too often assumed that these countries represent a homogeneous entity whereas in reality they are a very diverse group of countries - historically, culturally and economically. However, the experience of Soviet control and Soviet-inspired models of political and economic management did establish parameters within which these countries, albeit with national variations, operated.

Management formation and management development have been one of the boom industries arising from the collapse of the communist regimes of Central and Eastern Europe in 1989. It is not surprising that the process of system change - from command to market economy - has laid bare the weaknesses and deficiencies in knowledge and skills of individuals working in commercial and managerial positions within companies. The former system stressed specialist knowledge and skills, particularly of a technical nature, as enterprises were 
largely production units fulfilling the targets set by central planners, and the economic activities of enterprises were coordinated and controlled to a large degree by the ruling communist party. The operational activities of managers were therefore largely concerned with the practical implementation of enterprise plans - ensuring that necessary raw material inputs were obtained, that plant and equipment functioned effectively, or were repaired, bending the rules to meet (and exceed) the targets.

In general, managers in Central and Eastern Europe under the former system were well educated (the majority were graduates) and many held doctorates. The system of management formation (and to a lesser extent management development) was an integral part of the overall system of higher education. Attainment of managerial positions, especially above middle management level, was in general dependent more on party affiliation and personal contacts than on professional competence itself, although the latter was not totally discounted. Managers were expected to demonstrate a certain level of technical competence (for example, as engineers). However, they often lacked strategic and general management skills. This was understandable to the extent that enterprises had only limited involvement in the planning process and general management functions were generally exercised by a combination of enterprise management, communist party officials and trade union representatives. Enterprises lacked the autonomy of companies in market economies and thus required different kinds of skills to those prevalent in Western Europe. The stress on technical expertise and implementation was reflected in the overall production focused orientation of East European managers. This orientation became a marked handicap after 1989, as companies needed to become more responsive to markets and the obsolete or obsolescent level of technology, relative to western Europe, of many East European companies became a serious handicap to future development.

A number of factors had influenced the formation of managers under the communist regimes. Firstly there was a need to ensure the dissemination of the official ideology. The higher one rose within the enterprise hierarchy, the greater the significance of political affiliation became. Secondly, though deriving from this, political as well as social criteria were considered more important than purely economic criteria. A manager was more likely to be replaced for not 'towing the party line' than for being incompetent. In many cases incompetence resulted in being 'kicked upstairs'!

Is it possible to identify a Soviet/East European Model of management formation? The main lines of the Soviet model comprised the following elements: (a) university degree (b) allocation to an enterprise and (c) party affiliation. In general, university education preceded permanent employment in an enterprise. There were, however, also opportunities for non-graduate practising managers to obtain academic qualifications by part-time study. The relative weighting attached to the elements of the model varied between 
countries and at different points in time but in general political affiliation predominated over competence, the higher one climbed up the managerial hierarchy (often to the detriment of performance).

The functioning of the system also resulted in a number of distortions. Although the level and availability of general university education were on the whole comparable and (in some cases) superior to higher education in Western Europe, the vagaries of the allocation systems led to bizarre placements of graduates (e.g. shipbuilders in pharmaceutical enterprises [Edwards and Lawrence 1994]). Management development was also available but its development and effectiveness generally appeared somewhat limited when contrasted with the situation in the USA and Western Europe.

According to Granick (1975) East Germany and Romania were in the forefront of managerial training in communist Central and Eastern Europe and the Romanian government established a Management Development Centre in 1967. In East Germany advanced management training was already being undertaken within the framework of Higher Party Schools. A Management Development Centre was established in Hungary in the 1970s. Interestingly, because of their greater openness to market forces, the former Yugoslav republics, with their emphasis on workers' self -management, did not begin setting up similar centres until the 1980s, when the Brdo Management School was established by the Slovenian Chamber of Commerce in 1986 (Warner 1990), although businessrelated undergraduate courses were initiated in the late 1950s.

The development of management development centres was often supported by international organisations such as the United Nations (Romania) and the International Labour Organisation (Hungary). Within the overall context of the Soviet Model therefore there were national variations in the scope and effectiveness of the methods used to develop managers. These variations were determined in part by national cultural differences and by national variations in the degree of autonomy accorded to enterprise managers.

The collapse of the communist regimes made necessary a complete overhaul of management education. Marxist economics was discredited and managers in the region clearly lacked the foundation of market-economy knowledge and skills enjoyed by Western managers. The overhaul of the system has been strongly influenced by American practice and the Anglo-Saxon model, although the Romance and Nordic models have also made an input through collaboration between universities, for example, supported by the EU's Tempus Programme. The overhaul has also been influenced by national traditions preceding the communist take-over of power. For example, traditionally the Hungarian university system was patterned on the German (Prussian) Model. The current situation is thus often a patchwork of former Soviet, pre-communist and imported practices. 
A fundamental issue of this overhaul has concerned the meaning of management and the implicit meanings attached to the vocabulary of management. This semantic factor has varied from country to country. The following examples may serve as illustrations of this problematic. German has no native word for 'management' and 'manager'. In Romania the word 'manager' is used to refer to the managing director or chief executive officer in a company, i.e. to the top manager. In Poland, as far as the word 'manager' and 'management' are concerned, 'there is no term in Polish which carries the connotations we expect' and words used to describe persons in managerial positions carry specific connotations of commanding and governing (Jankowicz 1994).

This problem with meaning can be attributed to two main factors: the precommunist and communist experiences of the countries in the region. East Germany and the Czech provinces apart, the countries of the region were largely agricultural prior to 1945; the industrial base was accordingly weak and a managerial class was little more than embryonic. The industrialization of the countries of the region under communist leadership followed the Soviet Model which promoted bureaucratic rather than managerial-entrepreneurial modes of behaviour. The content and meaning of the work carried out by individuals in managerial positions consequently differed in significant ways. The difficulties with meaning are, however, frequently compounded when the visiting Western academic lacks knowledge and understanding of the local context (Ullmann 1995).

\section{The Anglo-Saxon Model}

Differences between the various West European models of management formation identified in this paper have to be understood in the context of the higher education systems of the various countries. The Anglo-Saxon tradition of higher education is one which takes place over a shorter period of years than that of the rest of Europe, with students normally entering the system at the age of eighteen. They take three years for a bachelors degree, unless it is a sandwich course with the equivalent of one year's practical experience incorporated into the programme, bringing it up to four years before completion. Postgraduate education can be in the form of a one year taught masters course or alternatively, three years of study for a $\mathrm{PhD}$. Whilst undergraduate education has until recent years been mainly a full-time activity, with grants available to students if they have gained a place, postgraduate education is much less easily supported and part-time modes of study have been quite common, particularly in the area of management.

The growth of management studies in higher education in Britain has taken place largely since the 1960s, within both the universities and the then polytechnic sector (the two sectors amalgamated in 1993). It can be seen as having taken three distinctive forms, postgraduate, undergraduate and post- 
experience. At postgraduate level, management education developed following the founding of London Business School (LBS) and Manchester Business School (MBS) in the mid 1960s. These two institutions offered two-year masters programmes in management, based upon the North American MBA model. LBS and MBS enjoyed preferential government funding over other business schools which developed within the university sector, especially amongst the technological universities like Bradford, Strathclyde and Aston but also in other newer universities like Warwick and Bath. In all but LBS and MBS, MBA programmes were of one year duration.

All these universities and others also offered undergraduate programmes in business and there were similar developments in the polytechnic sector. These were typically sandwich courses, with students gaining experience by working in business organisations as part of their studies. The polytechnic sector in particular also provided post-experience courses in management, at certificate and diploma levels. These courses were open to people who did not have a first degree but who were seeking qualifications in management, which could be gained on a part-time basis, whilst they continued with their job.

The Anglo-Saxon tradition in Britain has been one which has tended to discourage the need for qualifications in management, as employing organisations have typically seen management as the prerogative of the 'gifted amateur'. Management potential was most readily associated with those who had good interpersonal skills and who could demonstrate leadership. In some companies intellectual ability in the form of an arts degree would be seen as an asset but in others, particularly engineering companies, technical study on a parttime basis combined with practical experience would be sufficient for the first step on to the management ladder.

The growth of qualifications in management has been considerable since the mid 1980s but this has been driven more by demand from individuals seeking paper qualifications in the light of economic uncertainties, rather than by companies requiring a better qualified workforce of managers. In the mid 1980s only $12 \%$ of managers held a first degree with a further $6 \%$ professionally qualified and another 7\% having some form of post-school qualification (Handy et al 1987:11). At this time only 3,000 MBAs were produced each year but ten years later this had risen to 10,000 per year. Following the founding of the Management Charter Initiative in the mid 1980s, there has also been a growth of lower level post-experience qualifications, with extensions upwards to higher level national vocational qualifications (NVQs). Thus today some 40,000 managers in Britain are working on a part-time basis towards NVQs in management. 


\section{The Romance Model}

Management formation based around the Romance Model has more to do with obtaining formal qualifications immediately after leaving school, so that at the outset of a career, those who will become 'high-flyers' have already been identified through the recruitment system of employing organisations. Whereas British organisations have been very slow to recognise the value of formal higher education for their top managers, the situation has been different in other parts of the world, including the USA, Japan and the rest of Western Europe. The Handy Report for instance showed that only $24 \%$ of top managers in Britain held degrees, whereas the proportion was 65\% in France and $62 \%$ in West Germany but 85\% in the case of both the USA and Japan (Handy et al 1987:2).

Turning to the French approach, which is at the core of the Romance Model of management formation, the higher education system is divided between the grandes écoles, where entry is highly selective and the universities, where places are much more readily available on completion of the baccalaureate at the age of eighteen. Whereas a third of all French students entering higher education have a baccalaureate with commendation, in the case of the grandes écoles it is $80 \%$ (Hughes 1995). To enter the grandes écoles, students have to complete classes preparatoires (CPGE), where the emphasis is very much on mathematical ability, together with abstract logical thinking. Only 6\% of those going on to higher education enter the grandes écoles, with some 15,000 graduating annually from engineering schools and 8,000 from the business schools (Gordon 1994). Graduates from the grandes écoles will have studied for five years since their baccalaureate but are then in a position to be recruited by the top companies in France, as their future management cadre.

Whilst it appears on the surface to be very much a meritocracy that enters French management, the system is also highly socially selective, with the need to pay substantial fees to undertake the classes preparatoires and to attend the grandes écoles. It is therefore not surprising that two thirds of the places in classes preparatoires are filled by students from 'top-level intellectual professional' families, with only $15 \%$ coming from a working class background (Hughes 1995). Gordon argues that the management class in France is more of a hereditary class there than in other countries, citing a study which shows that one-quarter of managers in the top 200 German firms come from rich families compared with one-tenth in the USA but three-quarters in France (Gordon 1994:129).

The grandes écoles are supported by their local Chambers of Commerce and the education that they offer has an essentially vocational curriculum, with little or no research being conducted within these schools. This situation is however now changing and although research has traditionally been left largely to the universities, today some of the top French business schools are taking research more seriously. Such changes reflect the increasingly global market place for 
management education and the desire of the top French business schools to be recognised as offering an educational environment equal to the best in the world.

In Spain higher education has undergone many changes since the 1960s with very rapid expansion in student numbers since the 1970s. This has created considerable strains within the system and been the subject of government reviews and reforms. The top business schools in Spain are also elite institutions which claim to increase substantially the number of job offers which their students will receive on graduation. The business schools in Madrid and Barcelona in particular are in fierce competition and account for about $80 \%$ of student intake (Bruton 1994:308).

In Italy, completion of the school leaving certificate (maturità) at the end of secondary education means that students are qualified to go on to the university of their choice but drop out rates are high, especially in the first year (Brierley 1994). This author suggests that Italy can claim the first business school, with the Chancellery School of the Doge's Palace founded in Venice in the seventeenth century. However this early start has not been followed through and unlike France, Italy does not have an extensive network of business schools today, although there are some prestigious examples like the business school at the private Luigi Bocconi University in Milan. In the past in particular, Italian students have also gone to America for their business education, although in general in Italy there is still a conviction that managers are 'born' and acquire their skills in the course of actually managing companies, with this perception particularly strong amongst small and medium sized enterprises (Brierley 1994:191-192). Those who have gained MBAs will tend to work in large companies like Fiat or Olivetti or in foreign companies. There is thus a gulf between an elite who either attend one of the few prestigious business schools in Italy, or who study abroad and the majority of managers who have relied more on experience and entrepreneurship to create some of Italy's very successful smaller companies.

\section{The Nordic Model}

The Nordic Model centres on the German approach to management formation but as with the other models, each country provides its own variations. Like the British system until recently, (Western) German higher education is based upon a binary system whereby students who complete the school leaving qualification (Abitur or Reifezeugnis) can either enter the university sector or the Fachhochschulen (polytechnics). In other respects however, the German system differs considerably from the British, not least in terms of the time spent in higher education, which is generally over six years to complete a university diploma, although those in the Fachhochschulen are somewhat shorter in duration. Others will enter apprenticeships, combining study for qualifications and work experience. Another factor which delays German male students in 
completing their studies and embarking fully on their careers is the need to complete military service. The average age of German university students on graduation is twenty-eight. Thus not only do they enter the system older than British students, but also the drop out rates are higher than in Britain or in France. In the case of students on business programmes in German universities, it has been estimated that the drop out rate is about $40 \%$ during the first few years of the programme (Huntly 1993:106).

Although traditionally those with an engineering background have been particularly successful in management careers in German companies, there has been a considerable growth in the demand for and provision of business programmes in German universities during the last thirty years, usually developing out of economics departments. Business courses continue to attract large numbers of students and during the 1990s, contrary to the German general tradition, 'numerus clausus' was introduced to limit the number of students specialising in this area. Despite the already lengthy period of study to achieve a Diplom Kaufmann/frau, Randlesome argues that university graduates aspiring to the top ranks of management in Germany may well decide to continue to complete their doctorate. For instance he cites research showing that $53.8 \%$ of management board members of the 100 largest German companies held a doctorate (Randlesome 1994b:153).

Another way in which German business education differs from that in many other European countries is the apparent resistance to the introduction of American style business schools offering MBA programmes. Partnerships with other countries have however created some arrangements in recent years which enable German students to gain an MBA or similar qualification. Such programmes differ considerably from the traditional German university programmes in management, which are firmly rooted in social science disciplines like economics and sociology and are heavily theoretical and research based rather than vocational. Randlesome and others however suggest that German attitudes may be changing especially in companies, which have been critical of the theoretical curriculum offered in business in German universities. Randlesome cites a 1990 study of German company attitudes towards the MBA, which indicated that 53\% preferred graduates with the MBA and only $17 \%$ expressed a preference for those with the doctor title (Randlesome 1994:155).

Managers in the Netherlands are also very well educated with qualifications in engineering, law, economics or applied technical and business specialisms. As in Germany, engineers often move into general management but King suggests that Dutch attitudes reflect some of the British preference for the 'good all-rounder' as well as the German emphasis on specialised qualifications (King 1994:350351). As in Germany there is usually low mobility of managers between 
companies in the Netherlands and the companies in turn invest heavily in providing training and development opportunities for their managers.

\section{Discussion}

Each of the models discussed previously has its own distinctive and distinguishing characteristics. The Anglo-Saxon Model is characterized by a stress on generalism allied to entrepreneurialism and the drive for profit. In the United Kingdom the model has been personified in the 'gifted amateur' who, irrespective of background, education or training, is capable of achieving business success. In contrast the Romance Model cherishes intellectual elitism and that part of the educational system concerned with developing managers is seen as an incubator of cerebral Cartesian 'high flyers'. Whilst similarly stressing the importance of academic foundations and according substantial significance to high levels of qualification, the Nordic model has traditionally seen Technik - in particular as expressed in product engineering and manufacture - as the core of management. Finally, the former Soviet Model fostered production-oriented specialization within the overall context of the official ideology, although technical specialism could in many respects be a way of lessening the political dimension.

Having highlighted the key aspects which distinguish the respective models from one another, can any common threads be identified? First, all the models except traditionally the British version of the Anglo-Saxon model - attach great importance to academic development and training, and even in the United Kingdom the traditional view is rapidly eroding. Moreover, a common currency has evolved with the increasing dissemination of MBA programmes across Europe, irrespective of the locally dominant model. Second, and this applies to MBA programmes, the content and form of management courses remains strongly focused by the dominant local paradigm, albeit influenced to a degree by other models. Third, management development is increasingly providing portable qualifications both reflecting and encouraging management mobility. For example in the UK, the traditional model of internal upward mobility within one organization is yielding to greater mobility between organizations as managers can now provide evidence of universally accepted qualifications rather than just years of experience.

In the introduction, we expressed the view that each European country has developed a distinctive managerial cadre. This distinctiveness is reflected in each particular version of capitalism 'which is politically, socially and culturally embedded' (Zeleny 1993:46). How relevant is this to the situation and development of managers in Central and Eastern Europe?

First, the management cadres of individual countries derive from the general experience of economic and industrial development as well as from the 
particular system of education in each country. This experience is not consistent across the region. In this respect, compared to other former command economies of the region, the Czech Republic has a long-standing tradition of industrial development predating the communist period.

Second, management attitudes, behaviours and practices are embedded in deeprooted social values and attitudes. In Britain it has been the gifted amateur (and gentleman) while in the USA it is the entrepreneur. Such stereotypes are significant in revealing widespread expectations of what a manager should be.

Third, imports are attractive but also problematical. Not all practices admired abroad are necessarily appropriate nor will they fit culturally with local practices. Existing cultural traditions need not only to be recognized but also built upon. This is likely to maintain diversity.

Rather than finish this article with a conclusion, we would like to end with a number of propositions:

1) The Anglo-American model will continue to predominate because of general widespread American influence and the international currency of the MBA as a management qualification.

2) Notwithstanding the predominance of the Anglo-American model, national differences in the way various models of management formation are implemented will persist.

3) National variations in management formation will be conducive to better managerial practice, as managers in each country will be more closely attuned to broader social and cultural attitudes and values.

4) Individual national cultures may in fact be better aligned with different models of management formation.

For example, national cultures characterized by a strong degree of individualism (Hofstede 1980) may be considered appropriate locations for the AngloAmerican model. Such a situation may be considered to apply in Hungary, Poland and Slovenia. In more collectivist cultures such as the Czech Republic which also has a long-standing tradition of industrial development, the Nordic model with its stress on Technik may be more appropriate. On the other hand, the Romance model of management formation might be considered viable in, for example, Romania with its historial links to the Latin world and French culture and a more recent experience of industrialization. Such a culture-based approach is in line with Machkova's (1998) notion of zones of cultural affinities ('zones d'affinités culturelles') although not following Machkova's proposed classification which is specifically related to marketing policies.

These propositions, moreover, are likely to be testable only in the longer term, on the basis of studies conducted in each of the countries of CEE. The development of managers in Western Europe and North America seems to 
indicate that this development takes place in association with the system of general education and the cultural context. External influences tend also to be mediated in a similar way. It is also the experience of the advanced market economies that management does change as a consequence of changes in the external environment, the introduction of 'foreign' ideas and self-renewal. The general situation in Central and Eastern Europe offers substantial opportunity for managers in the region to learn and change, if they are to meet the considerable challenges facing them.

\section{References}

Bögel, G., Edwards, V. and Wax, M. (1997) Hungary Since Communism: The Transformation of Business, Basingstoke and London: Macmillan.

Brierley, W. (1994) 'The business culture in Italy' in Randlesome, C., Brierley, W., Bruton, K., Gordon, C., and King, P. Business Cultures in Europe, Second Edition, Oxford: Butterworth Heinemann.

Bruton, K. (1994) 'The business culture in Spain’, in Randlesome, C. et al. Ibid.

Edwards, V. and Lawrence, P. (1994) Management Change in East Germany, London and New York: Routledge.

Edwards, V. and Lawrence, P. (1995) The Transition to Capitalism in Slovenia, Buckinghamshire Business School Research Paper RP 3/95.

Edwards, V. and Lee, G. L. (1997) 'The Role of Academe in Management Formation in Western \& Eastern Europe’, Aston Business School Research Paper, RP9727.

Edwards, V., Polonsky, G. and Polonsky, A. (In Press) Transformation in the Russian Province: Enterprise Continuity and Change, Basingstoke and London: Macmillan.

Gordon, C. (1994) 'The business culture in France’, in Randlesome, C. et al. Ibid.

Granick, D. (1975) Enterprise Guidance in Eastern Europe, A Comparison of Four Socialist Economies, Princeton UP.

Handy, C., Gow, I., Gordon, C., Randlesome, C. and Moloney, M. (1987) The Making of Managers, a report on management education, training and development in the USA, West Germany, France, Japan and the UK, London: National Economic Development Office.

Hofstede, G. (1980) Culture’s Consequences, London: Sage, 1980.

Hughes, S. (1995) 'Rich kids dominate degree block', The Times Higher, August 4:8.

Huntly, C. (1993) Participation in Higher Education: Problems in Comparing British, French and German Business Education Systems, unpublished MSc thesis.

Jankowicz, A. (1994) 'Parcels from Abroad: The Transfer of Meaning to Eastern Europe', Journal of European Business Education, 3(2), 1-19.

King, P. (1994) 'The business culture in the Netherlands', in Randlesome, C. et al. Op. Cit.

Lawrence, P. (1994) “ “In Another Country” or the Relativization of Management Learning', Management Learning, 25 (4) 543-561. 
Lee, G. L. and Smith, C.D. (Eds.) (1992) Engineers and Management: International Comparisons, London: Routledge.

Machkova, H. (1998) 'Pratiques et politiques de marketing en Europe de l'Est', revue française de gestion, 117 (1), 107-115.

Randlesome, C. (1994) The Business Culture in Germany: Portrait of a Power House, Oxford: Butterworth Heinemann.

Ullmann, A (1995) 'TeMAFL: Teaching Management as a Foreign Language, Some Observations and Reflections about Management Education in Central Europe', in Culpan R. and Kumar B. (eds.) Transformation Management in Postcommunist Countries, Quorum Books.

Warner, M. (1990) 'Management Versus Self-Management in Yugoslavia', Journal of General Management, vol. 16(2) Winter, 20-38.

Zeleny, M., (1993) 'Reforms in Czechoslovakia: Traditions or Cosmopolitanism?', in Maruyama, M. (ed.) Management Reform in Eastern and Central Europe, Dartmouth, pp. 45-64. 